\title{
Pasientoverlevering kan bli tryggere og sikrere
}

Når et helseteam overleverer kritisk pasientinformasjon til et annet team i forbindelse med operasjon, kan det gå ut over pasientsikkerheten.

\section{Forfattere}

\section{Kristin Brun-Pedersen}

Sykepleier, tidligere bachelorstudent

Institutt for samfunnsmedisin og sykepleie, NTNU

\section{Beate André}

Sykepleier og førsteamanuensis

Institutt for samfunnsmedisin og sykepleie, NTNU og NTNU Senter for helsefremmende forskning

\section{Nøkkelord}

\section{Pasientsikkerhet Kommunikasjon rapport Operasjon}

Sykepleien 2017 105(64383)(e-64383)

DOI: https://doi.org/10.4220/Sykepleiens.2017.64383

\section{HOVEDBUDSKAP}

Rapporten ved overlevering av pasienter fra sengepost til operasjonsstua er ustrukturert og kortfattet. En uklar og utydelig kommunikasjon kan gå ut over pasientsikkerheten. En standardisering av overleveringsprosessen ved hjelp av sjekklister, protokoller og kommunikasjonshjelpemidler bedrer pasientsikkerheten og kvaliteten ved kirurgiske inngrep. Slike tiltak må imidlertid være faglig forankret og oppleves som nyttige og relevante for at de skal ha ønsket effekt. 
Kirurgiske komplikasjoner som kunne vært unngått, er årsaken til en stor andel av medisinsk relaterte skader og dødsfall globalt. Pasientsikkerhet i forbindelse med kirurgi er dermed blitt et betydelig helseproblem (1).

En del av det operative forløpet er å overlevere pasienten i slusa, og her finnes det til nå lite forskning i Norge. Tall fra USA tilsier likevel at kommunikasjonssvikt ved ansvarsoverlevering av pasienter er en sentral årsak til feil og uønskete hendelser i forbindelse med operasjon (2).

\section{Trygg kirurgi}

Verdens helseorganisasjon (WHO) utviklet i 2009 retningslinjer for trygg kirurgi på bakgrunn av dette tiltakende problemet. Målet med retningslinjene er å forbedre sikkerheten rundt kirurgiske inngrep gjennom et standardisert sett med sikkerhetsrutiner som kan benyttes i alle land.

Retningslinjene baserer seg på fire mål for å oppnå sikker praksis. Et av målene gjelder samhandling, samarbeid og kommunikasjon innad i det kirurgiske teamet. I beskrivelsen legges det vekt på god kommunikasjon samt effektiv utveksling av kritisk pasientinformasjon fra ett helseteam til et annet når de overleverer pasienten (1).

\section{Risikoområder}

Kunnskapssenteret viser til at det i Norge ble meldt om 9536 uønskete hendelser i spesialisthelsetjenesten i 2014 (3). 1500 (19 prosent) av hendelsene ble assosiert med betydelig personskade eller død, og 14 prosent av hendelsene ble forbundet med pasientadministrative forhold.

Et av risikoområdene som blir beskrevet, er kommunikasjonssvikt ved overflytting og/eller overføring av pasientansvar (3). Dette viser at det også foreligger visse utfordringer knyttet til pasientsikkerhet og kvalitet i det norske helsevesenet. 


\section{$\equiv$ «Det trengs gode systemer og en organisasjon som hele tiden jobber for å bedre sikkerhet og kvalitet.»}

De siste årene har det skjedd en utvikling innen årsaksteorier for uønskete hendelser i helsetjenesten. De fleste uønskete hendelsene regnes nå som et resultat av svikt i systemet og organiseringen av helsetjenesten. Oppmerksomheten er flyttet fra enkeltindividets ansvar over på organisasjons- og systemfaktorer som skaper omgivelser der uønskete hendelser og pasientskader kan forekomme (4).

Denne utviklingen tyder på at flinke, individuelle fagfolk og godt samarbeid innad i et kirurgisk team ikke er nok. Det trengs gode systemer og en organisasjon som hele tiden jobber for å bedre sikkerhet og kvalitet. Organisasjoner som ønsker å lykkes i arbeidet med å forebygge feil og uønskete hendelser, har større sjanse for å lykkes dersom de flytter oppmerksomheten fra individet over på samspillet mellom mennesker og organisering (5).

\section{Kvalitetsutvikling}

Kvalitet og pasientsikkerhet ved ansvarsoverlevering av pasienter er viktige fokusområder. Forskning viser at standardisering av prosedyrer samt bruk av kommunikasjonshjelpemidler og sjekklister kan bidra til redusert risiko og færre uønskete hendelser $(6,7)$.

Til tross for dette kan det være utfordrende å implementere sjekklister og andre hjelpemidler innenfor helsevesenet ettersom det er en komplisert og til tider uforutsigbar organisasjon. Derfor kan det virke mot sin hensikt å innføre slike hjelpemidler (8).

Kvalitetsutvikling innenfor sykepleiefaget avhenger av et kritisk syn på de systemene som har til hensikt å sikre kvalitet og sørge for optimal sykepleiepraksis. Organisasjonen må gå gjennom rutiner og prosedyrer samt endre der det er indikert (9). 
En forutsetning for kvalitetsutvikling innenfor

sykepleie er derfor at sykepleiere selv er aktive i å reflektere og evaluere egen praksis. Dette bidrar til læring og positiv endring innenfor sykepleiefaget (9). En ferdigutdannet sykepleier skal ha handlingskompetanse til å arbeide systematisk med faglig kvalitetsutvikling. Sykepleieren skal dessuten medvirke til å utvikle sin egen yrkesrolle og ved å delta i klinisk forskning (3).

\section{Metode}

Bakgrunnen for denne artikkelen er et forskningsprosjekt som førsteforfatter gjennomførte i forbindelse med avsluttende eksamen i sykepleie. Vi gjennomførte prosjektet over en tidsperiode på to uker i 2016. Prosjektet var en observasjons- og kartleggingsstudie som ble gjennomført ved to ulike operasjonsstuer på St. Olavs Hospital.

Studien var et samarbeidsprosjekt mellom sykepleierutdanningen ved NTNU og Fremtidens Operasjonsrom (FOR) ved St. Olavs Hospital. FOR er en arena for forskning og fagutvikling på alle utdanningsnivåer. Fagrådet i FOR godkjente prosjektet før oppstart.

Vi samlet inn dataene med strukturert observasjon ved å bruke et tilpasset observasjonsskjema. I tillegg noterte vi ned ustrukturerte observasjoner underveis $(10,11)$. Fordelen med observasjon som metode er muligheten til direkte å fange opp ulike hendelser og holdninger. Ulempen er at dataene kan påvirkes av observatørens holdninger, verdier og fordommer. De kan også forvrenges av observatørens forventninger til hva de kommer til å finne $(10,11)$.

For å redusere innvirkningen av slike faktorer brukte vi et standardisert observasjonsskjema med objektive verdier for å kartlegge. I tillegg benyttet vi ustrukturert observasjon. Vi analyserte dataene ved hjelp av frekvensanalyse $(10,11)$. 
Vi spurte avdelingene der vi observerte, på forhånd om de ville delta i forskningsprosjektet. Alle opplysningene som vi samlet inn under observasjonene, ble behandlet konfidensielt.

Veilederen ved NTNU og fagrådet i FOR godkjente observasjonsskjemaet før vi startet observasjonene (vedlegg 1).

\section{Resultater}

Totalt gjennomførte vi 39 observasjoner fordelt på én operasjonsstue som utførte gynekologiske inngrep på voksne, og én som utførte generelle inngrep på barn. Inngrepene varierte i størrelse og omfang.

I operasjonsslusa ble pasienten overlevert av en sykepleier fra sengepost og mottatt av en anestesisykepleier og en operasjonssykepleier. I noen tilfeller var også pårørende til stede under overleveringen. De fleste av sluserapportene som vi observerte, ble gjennomført på ett til tre minutter. Det ble gitt informasjon om pasientens nåværende tilstand og hvilke forberedelser som var gjort i forkant av operasjonen (se tabell 1).

Eksempler på informasjon kan være pasientens navn og personnummer, premedikasjon, vannlating, fasting og bedøvelseskrem som brukes til lokalbedøvelse ved kirurgiske inngrep på barn. 
Tabell 1: Tid brukt på rapport

\begin{tabular}{ll} 
Tid brukt på rapport & Frekvens (prosent) \\
\hline 1-3 minutter & $21(53,9 \%)$ \\
4-6 minutter & $16(41 \%)$ \\
7-9 minutter & $2(5,1 \%)$ \\
Totalt & $39(100 \%)$ \\
Tid på rapport fordelt på små inngrep & Frekvens (prosent) \\
\hline 1-3 minutter & $13 / 24(41,6 \%)$ \\
4-6 minutter & $10 / 24(54,2 \%)$ \\
7-9 minutter & $1 / 24(4,2 \%)$ \\
Tid på rapport fordelt på større inngrep & Frekvens (prosent) \\
\hline 1-3 minutter & $8 / 15(53,3 \%)$ \\
4-6 minutter & $6 / 15(40 \%)$ \\
7-9 minutter & $1 / 15(6,7 \%)$ \\
\hline
\end{tabular}

Tabell 2: Fordeling av størrelse på inngrep

\begin{tabular}{ll} 
Størrelse på inngrep & Frekvens (prosent) \\
\hline $10-30$ minutter (lite inngrep) & $24(61,5 \%)$ \\
$30-120$ minutter (større inngrep) & $15(38,5 \%)$ \\
Totalt & $39(100 \%)$
\end{tabular}

Informasjonen som postsykepleieren overførte til operasjonspersonalet, ble ikke gitt etter en standardisert prosedyre. Hva slags informasjon og hvordan informasjonen ble videreformidlet, var forskjellig fra gang til gang. Ved flere tilfeller ga sykepleieren fra sengepost veldig lite informasjon, og kommunikasjonen foregikk i hovedsak mellom pasienten og anestesisykepleieren.

En preoperativ sjekkliste er en sjekkliste fra sengepost som skal være utfylt av postsykepleieren når pasienten forberedes til operasjon. Den skal også være med pasienten ned til operasjonssalen. Sjekklisten inneholder informasjon om hvordan pasienten er forberedt til operasjonen. En slik sjekkliste er rutine på de observerte avdelingene. 


\begin{tabular}{ll} 
Preoperativ sjekkliste & Frekvens (prosent) \\
\hline Sjekkliste foreligger & $31 / 39(80 \%)$ \\
Sjekkliste foreligger ikke & $8 / 39(20 \%)$ \\
Sjekkliste fullstendig utfylt & $12 / 31(38,7 \%)$ \\
Sjekkliste ikke fullstendig utfylt & $19 / 31(61,3 \%)$ \\
Sjekkliste fullstendig utfylt ved mindre inngrep & $7 / 24(29,1 \%)$ \\
Sjekkliste fullstendig utfylt ved større inngrep & $5 / 15(33,3 \%)$ \\
&
\end{tabular}

\section{Diskusjon}

Kommunikasjonssvikt blant operasjonspersonalet under et kirurgisk forløp er en utbredt årsak til uheldige hendelser før, under og etter operasjon (9). Kommunikasjonssvikt var hovedårsaken til nærmere 70 prosent av alle uønskete hendelser som ble rapportert i perioden mellom 1995 og 2005 i USA (2).

Observasjoner fra studien vår viste at kommunikasjonen og informasjonsutvekslingen i slusa før operasjon var ustrukturert og kortfattet. Det var ingen fastsatt struktur eller innarbeidet rutine for hvordan kritisk pasientinformasjon skulle videreformidles til operasjonssalen. Det samme gjaldt hvilken pasientinformasjon som skulle videreformidles. I tillegg varierte det hvor mye informasjon sykepleieren videreformidlet.

Sykepleiere har ulik erfaring og dermed forskjellige vurderinger av hver enkelt pasient. Det kan gjøre sluserapportering til en sårbar prosedyre med risiko for at viktig informasjon går tapt (12).

Vi observerte også at sykepleieren i flere tilfeller kommuniserte veldig lite muntlig ved sluserapportering. Ofte foregikk informasjonsutvekslingen mellom pasienten eller de pårørende og operasjonspersonalet. Pasienter som skal gjennom et kirurgisk inngrep, er ofte preget av stress og bekymringer (13). 


\section{Kommunikasjonssvikt}

De senere årene har det blitt rettet mer oppmerksomhet mot hvordan hver enkelt helsearbeider kan være med på å påvirke utfallet ved kirurgiske inngrep (9). Hver overlevering medfører risiko for at viktig informasjon blir for dårlig kommunisert eller forsvinner på veien. Dette kan i verste fall føre til at behandlingen blir forsinket eller tilstanden til pasienten forverret (14).

Det er viktig å kommunisere effektivt og konkret ved pasientoverlevering for å sikre videre behandling og hindre uønskete hendelser og pasientskader (15). Kirurgiske pasienter er spesielt utsatt for feil under overlevering nettopp fordi et kirurgisk inngrep er komplekst (16). Forskning gjort av Greenberg og medarbeidere (6) viser at kommunikasjonssvikt ligger bak mange uønskete hendelser som har ført til skade på kirurgiske pasienter.

\section{三 «Kirurgiske pasienter er spesielt utsatt for feil under overlevering nettopp fordi et kirurgisk inngrep er komplekst.»}

Videre sier de at det er like sannsynlig at svikt i kommunikasjonen skjer pre- og peroperativt som postoperativt. Det er vanligst at informasjon om pasienten ikke blir formidlet til mottakeren, eller at informasjonen ikke blir forstått på riktig måte av mottakeren (9).

Kommunikasjonssvikt forekommer ofte i forbindelse med ansvarsoverlevering av pasienten og overføring av pasienten fra en avdeling til en annen.

Standardiserte overleveringsprosedyrer og overføringsprotokoller kan redusere risikoen betydelig for pasienten (9).

\section{Kunnskap gir tiltak}


Ny kunnskap om aktuelle risikofaktorer når pasienter overleveres, har ført til at ulike tiltak er implementert ved operasjonssaler internasjonalt. Det hyppigst brukte hjelpemiddelet er standardiserte skjemaer og sjekklister. Studier gjort i etterkant har vist at slike intervensjoner har ført til færre feil og skader og flere vellykkete overleveringer (15).

Samtidig er det utviklet en bredere forståelse for at det ikke er nok å fokusere mer på kommunikasjon innad i operasjonsteamet og innføre sjekklister. For å oppnå kvalitet og mer oppmerksomhet på pasientsikkerhet trengs det en kombinasjon av ulike tiltak (15).

Standardiserte overleveringsprosedyrer kan bidra til meningsfull kommunikasjon og positive pasientutfall, for eksempel ved at sykehuset innfører kommunikasjonshjelpemidler til å organisere informasjonen i et logisk og lettfattelig mønster (18).

Funn fra våre observasjoner viste at sluserapportene var effektive i den forstand at over halvparten ble gjennomført på ett til tre minutter. Ved mindre inngrep varte sluserapporten i fire til seks minutter, og ved større inngrep ble de fleste sluserapportene gitt på ett til tre minutter (se tabell 1).

Slike resultater tyder på at rapportene var korte og effektive uavhengig av størrelsen på og omfanget av inngrepet. Dette kan tyde på at effektivitet ved sluserapportering er et sentralt element. Det er en risiko for at effektiviteten går ned og sluserapporten blir mer tidkrevende enn nødvendig når sykehus implementerer kommunikasjonsteknikker og standardiserer overleveringsprosessen (8).

\section{Feilinformerer ved stress}


Det finnes mange faktorer som kan tenkes å påvirke hvordan informasjon videreføres fra et helseteam til et annet. Feil og svikt innenfor et system forekommer sjelden som et resultat av én utrygg handling (1). Menneskelige feil er uunngåelige, spesielt i stressete situasjoner (8). Innvirkende faktorer er blant annet stor arbeidsmengde, manglende kunnskap, evner eller erfaring, stressende miljø og mental utmattelse eller kjedsomhet (1).

Forskning viser også at sykepleiere har en mindre hensiktsmessig måte å kommunisere på i stressete situasjoner, sammenliknet med ikke-stressete situasjoner $(19,20)$. Mennesker er med andre ord feilbarlige, noe kompliserte institusjoner som stiller høye krav til sikkerhet og kvalitet, må ta høyde for (1).

\section{三 «Feil og svikt innenfor et system forekommer sjelden som et resultat av én utrygg handling.»}

Hensikten med en overleveringsrapport er at den skal gi essensiell, oppdatert og spesifikk informasjon om pasienten samtidig som den gir mulighet til å stille spørsmål og få svar (17). Fellesfaktorer for en vellykket overlevering av en pasient er blant annet at informasjonen formidles på en effektiv måte uten forstyrrelser, at den inneholder konkret informasjon og gjennomgår relevante data.

I arbeidet med en forsvarlig informasjonsutveksling kan det være nyttig å bruke standardiserte verktøy og retningslinjer, et strukturert språk og sjekkliste for kommunikasjonen (20).

\section{Preoperativ sjekkliste}


En preoperativ sjekkliste bør foreligge når pasienten overleveres til operasjon, da denne typen dokumentasjon bidrar til å sikre at rett inngrep utføres på rett pasient, og at pasienten er riktig forberedt (13). En slik sjekkliste var rutine ved avdelingene i studien vår. I 80 prosent av overleveringene var sjekklisten med pasienten ned til operasjonssalen.

Våre observasjoner viser likevel at over halvparten av sjekklistene ikke var fullstendig utfylt eller ikke utfylt i det hele tatt. Det var heller ingen forskjell i oppslutningen rundt sjekklisten ved større inngrep sammenliknet med mindre inngrep (se tabell 3). Resultatene tyder på at det forelå rutinesvikt blant sykepleierne på sengepost. Sjekklisten ble heller ikke, med få unntak, vist frem i slusen før operasjon og sjelden etterspurt av operasjonspersonalet.

Det kan tenkes at sjekklisten først og fremst fungerer som en huskeliste for sykepleierne på sengeposten når det gjelder hvordan pasienten skal forberedes til operasjon, og at den dermed regnes for å være til liten nytte på operasjonsavdelingen. En så liten oppslutning rundt sjekklisten kan også tyde på at de som skal bruke den, synes den er irrelevant og unyttig (8).

\section{三 «Resultatene tyder på at det forelå rutinesvikt blant sykepleierne på sengepost.»}

Egen erfaring fra praksis ved kirurgisk sengepost

tilsier at holdninger og rutiner knyttet til bruk av en preoperativ sjekkliste er ulik fra avdeling til avdeling. Den preoperative sjekklisten ved kirurgisk sengepost var en sentral del av forberedelsen av pasienten.

Sjekklisten var alltid med pasienten ned til operasjonssalen og ble vist frem til operasjonspersonalet ved overlevering. 
Bruk av sjekkliste regnes som et viktig verktøy til å bekjempe feil og uønskete hendelser i helsevesenet. Den kan veilede brukeren samtidig som den kan bekrefte fullførte gjøremål (8). Bruken av sjekklister som et middel for å forbedre kvaliteten på kirurgiske overleveringer ser også lovende ut, ifølge forskning gjort på området (7).

Hovedformålet med å implementere sjekklister er som regel å sørge for at flest mulig følger rutiner og praksis, samt at andelen personlige feil reduseres. På den måten bidrar sjekklisten til å sikre gode pasientutfall og øke effektiviteten og kvaliteten (8).

\section{Uforutsette faktorer}

På grunn av store variasjoner og uforutsette menneskelige faktorer som virker inn på pasientens behandling, kan det være utfordrende å implementere sjekklister ved helseinstitusjoner.

Kulturelle faktorer og holdninger til det å bruke hjelpemidler kan også representere en utfordring. Noen helsearbeidere kan for eksempel føle at det å bruke hjelpemidler for å huske, er et tegn på personlig svakhet (8). Enda viktigere er det kanskje at sykepleiere kan føle at sjekklister begrenser deres kliniske vurderinger og autonome beslutninger.

Helsearbeidere kan også bli så avhengige av den i sitt arbeid at det forstyrrer deres profesjonelle bedømming og objektivitet når de vurderer pasienten. I så fall risikerer man at sjekklisten virker mot sin hensikt. Overforbruk av sjekklister og standardiserte hjelpemidler i kliniske situasjoner kan føre til at brukerne blir overveldet. På den måten kan sjekklister bli til et hinder og ikke et hjelpemiddel i arbeidet.

I verste fall kan overforbruk av sjekklister føre til forsinket behandling av pasienten (8). Når sjekklister implementeres og brukes, er det viktig med nøye faglig vurdering og oppfølging dersom de skal ha den ønskete effekten og nytteverdien (8). 


\section{Studiens begrensninger}

Det finnes flere begrensninger ved studien vår. Blant annet observerte vi kun to operasjonsstuer ved ett sykehus i Norge. Sluserapportering før operasjon er en liten del av det operative forløpet, og på bakgrunn av observasjonene våre kan vi derfor ikke konkludere noe generelt om pasientsikkerheten ved kirurgiske inngrep.

Videre studier og forskning på området bør derfor ta for seg flere avdelinger og sykehus for å få et mer helhetlig bilde. I tillegg kan videre forskning omfatte hele det operative forløpet for å undersøke hvordan pasientsikkerhet og kvalitet blir ivaretatt pre-, per- og postoperativt.

\section{Konklusjon}

Resultatene fra studien vår viste at preoperative sjekklister ved avdelingene var lite brukt. Observasjonene viste også at rapporten ved overlevering av pasient i slusa var ustrukturert og kortfattet.

Ifølge forskning gjort på området er det utfordringer knyttet til kommunikasjon ved ansvarsoverlevering av pasienten, noe som kan gå ut over pasientsikkerheten. En standardisering av overleveringsprosessen ved hjelp av sjekklister, protokoller og kommunikasjonshjelpemidler bedrer pasientsikkerheten og kvaliteten ved kirurgiske inngrep.

Slike tiltak må likevel være faglig forankret og oppleves som nyttige og relevante for brukerne for at de skal ha ønsket effekt. Derfor må organisasjoner iverksette og evaluere standardiserte tiltak ved overleveringsprosessen på systemnivå før de implementerer dem. På den måten kan de bidra til å sikre et miljø der pasientsikkerhet og kvalitet står sentralt.

\section{Referanser}


1. World Health Organisation. WHO Guidelines

for safe surgery: Safe Surgery Saves Lives. 2009.

Tilgjengelig fra:

http://www.who.int/patientsafety/safesurgery/tools_resources/9789241598552/en/ (nedlastet 04.12.2017).

2. Aase K. Pasientsikkerhet - hendelser, begreper og omfang. I: Aase K, red. Pasientsikkerhet- teori og praksis i helsevesenet. Oslo: Universitetsforlaget; 2010.

3. Kunnskapssenteret. Årsrapport 2014 for meldeordningen for uønskete hendelser i spesialisthelsetjenesten. Nasjonalt kunnskapssenter for helsetjenesten, Helse- og omsorgsdepartementet. 2015.

4. Westphal DW, Forbes MP, Barach P.

Pasientsikkerhet i et internasjonalt perspektiv: status, utfordringer og fremtidens ideal. I: Aase K., red. Pasientsikkerhet - teori og praksis i helsevesenet. Oslo: Universitetsforlaget; 2010.

5. Sosial- og helsedirektoratet. Og bedre skal det bli! Nasjonal strategi for kvalitetsforbedring i sosialog helsetjenesten. 2005.

6. Greenberg CC et al. Patterns of communication breakdowns resulting in injury to surgical patients. J Am Coll Surg 2007;4:533-40.

7. Puncher PH et al. Effectiveness of interventions to improve patient hangover in surgery: A systematic review. Surgery. 2015;158(1):85-95.

8. Birgitte HM, Pronovost PJ. The checklist - a tool for error management and performance improvement. Journal Of Critical Care. 2006;21:2315. 
9. Bjøro K, Kirkevold M. Kvalitet og

kvalitetsutvikling i sykepleie. I:

Kristoffersen NJ, Nortvedt F, Skaug E-A, red. Grunnleggende sykepleie. Oslo: Gyldendal

Akademisk; 2012. s. 343-70.

10. Joint Commission Center for Transforming

Healthcare. Tilgjengelig fra:

http://www.centerfortransforminghealthcare.org/assets/4/6/handoff_comm_storyboard.pdf (nedlastet 22.12.2014).

11. Polit DF, Beck CT. Nursing research, principles and methods. Philadelphia: Lippincott, Williams \& Wilkins; 2004.

12. Bjørk IT, Solhaug M. Fagutvikling og forskning i klinisk sykepleie - en ressursbok. Oslo: Akribe; 2008.

13. Gilmour D. Perioperative care. I: Pudner R, red. Nursing the Surgical Patient. 3. utg. Elsevier Limited; 2010.

14. Haukelien H, Vike H, Bakken R. Kompetanse og faglig infrastruktur i helse- og omsorgstjenesten: Evaluering av prosjektet Etter- og videreutdanning i kommunehelsetjenesten (EVUK).

Telemarksforsking; 2009.

15. Clarke D et al. Achieving the 'perfect handoff' in patient transfers: building teamwork and trust. Journal of Nursing Management. 2012. 20:592-8.

16. Amato-Vealey EJ, Barbra MP, Vealey RJ. Hand-off communication: A requisite for perioperative patient safety. AORN J 2008;88(5):763-70.

17. Rothrock JC. Alexander's Care of the Patient in Surgery. I: Murphy EK, red. Patient safety and risk management. 15. utg. St. Louis, Missouri: Elsevier Mosby; 2015. s. 16-41. 
18. Eberhardt S. Improve handoff communication with SBAR. Nursing. 2014;44(11):17-20.

19. Fuchshuber P, Grief W. Creating effective communication and teamwork for patient safety. I:

Tichansky DS, Morton J, Jones DB., red. The SAGES Manual of Quality, Outcomes and Patient Safety. New York: Springer Verlag; 2012.

20. André $\mathrm{B}$ et al. Exploring nursing staffs communication in stressful and non-stressful situations. Journal of Nursing Management. 2015. DOI: $\underline{10.1111 / \text { jonm.12319. }}$. 